\title{
Designating Marine Reserves Is not Just an Ecological Process
}

\author{
Jing $\mathrm{Li}^{1}$ \\ ${ }^{1}$ Department of Public Basic Courses, Wuhan Maritime Vocational College, China \\ Correspondence: Jing Li, Shekou Economic Development Area of North Hankou, Huangpi, Wuhan 430311, \\ Hubei, China. Tel: 85-157-1715-9589. E-mail: 420220233@qq.com
}

Received: July 22, 2015 Accepted: March 27, 2016 Online Published: September 29, 2016

doi:10.5539/ep.v5n2p72 URL: http://dx.doi.org/10.5539/ep.v5n2p72

\begin{abstract}
Marine natural resource and ocean species are endangered because of human activities. In order to avoid marine natural resource depletion and recover marine ecosystem, marine reserves are created. The report will introduce the marine reserve definition and its functions. In addition, the report will describe three main marine reserves in Australia. Moreover, it will explain why designating marine reserves is not an ecological process.
\end{abstract}

\section{Introduction}

With the development of industrialization, human has started to exploit the marine, so the ocean is suffering from destruction. Many types of marine vegetation, fish species and some rare organisms are disappeared or endangered because of marine pollution and human activities such as fishing. Therefore, if people need only look at a map of the coast or walk around a coastal community to find names of places like Sheepshead Bay, where no one's caught a sheepshead in a generation; Halibut Cove, where no one may ever catch a halibut again; Jewfish Creek, where no one remembers the last jewfish; or Salmon Run, where the last run occurred before anyone alive today was born, it must be a lamentable thing (Jack, 2004).

As a consequence, in order to protect the natural marine heritage and its biodiversity, many marine biologists assert that create some marine reserves to reduce the negative influences which are resulted from people activities on oceans. Marine reserve is an area of sea in which all consumptive or extractive uses, including fishing, are effectively prohibited and other human interference is minimized to the extent practicable, and this definition was originally adopted by the World Conservation Union (IUCN) nearly fifty years ago (Pinheiro et al., 2009). The simple definition is that the marine reserve is an area of the sea which has legal protection against fishing or development. The marine reserve is different from a marine park, but to some extent there is some overlap in usage or same function in these two places.

The marine reserve has a number of potential actions, and these potential benefits are able to be divided into four broad categories: the first one is protect ecosystem structure, function, and integrity; the second one is improve fisheries; the third one is expand knowledge and understanding of marine system; the last one is enhance nonconsumptive opportunities (John, 2008). Therefore, the marine reserve is a good tool for marine environmental management to protect ocean species diversity and habitats. Currently, according to the different protected objects, there are five types of marine reserves which have been built in the world: Estuaries, Coral reefs, Marine, Islands reefs and Littorals.

\section{Current Australia Marine Reserves}

Australia has rights and responsibilities over some 16 million square kilometers of ocean, which is more than twice the area of its continent. There are the most ecologically diverse areas of the Australian marine environment in the world, ranging from arctic to sub-tropical areas. In addition, the Australian oceans provide a multitude of natural resources for seafood supply and people entertainment. Therefore, the marine reserves are much more necessary and significant for Australia to keep the marine environmental health (Preen, 1998). There are many marine reserves in Australia such as Great Barrier Reef Marine Park, Port Phillip Heads Marine National Park, Australian Whale Sanctuary, Huon Commonwealth Marine Reserve, South-East Commonwealth Marine Reserve Network, Portsea Hole, Bunurong Marine National Park and Tasman Fracture (Books, 2010). Figure 1 is the map of main Australian marine reserves. 


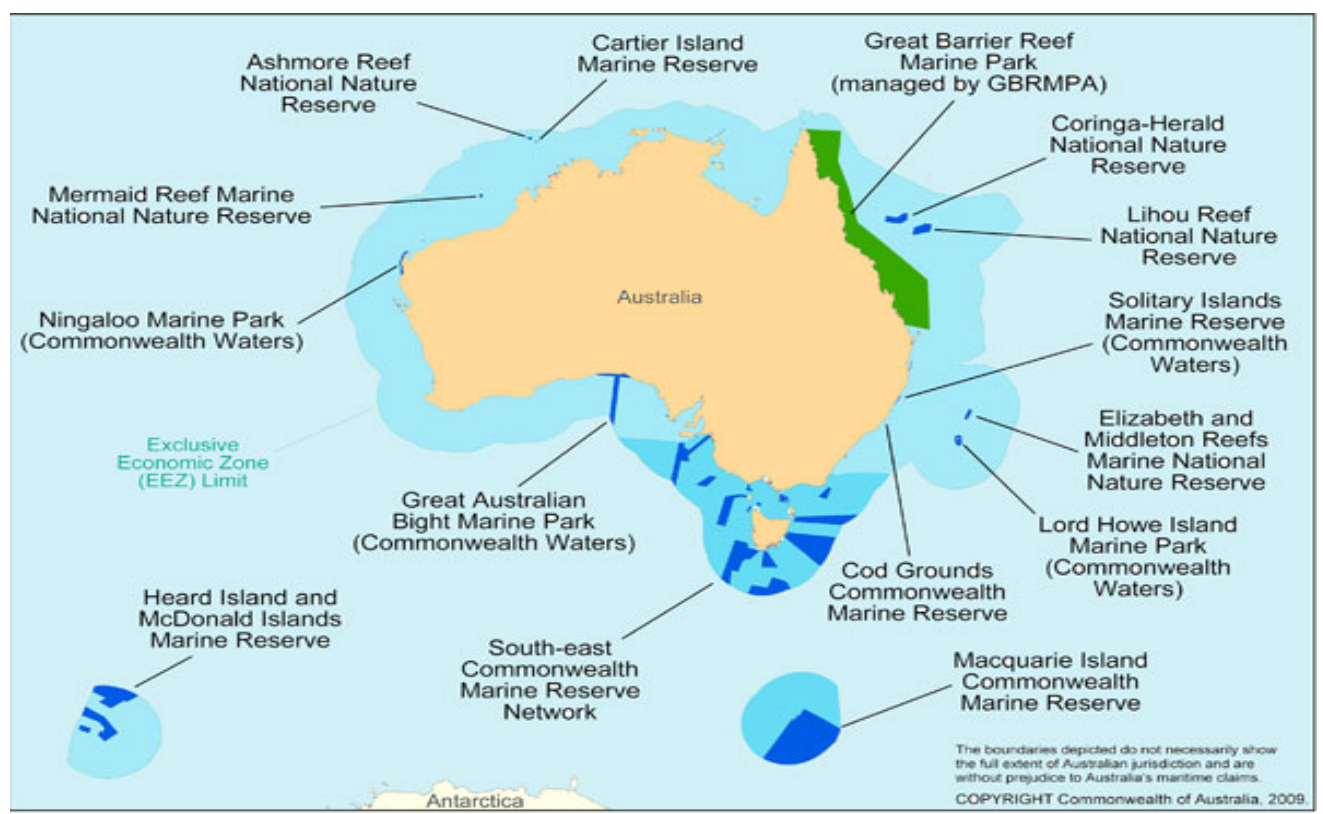

Figure 1. Main Australian marine reserves

a). The Great Barrier Reef Marine Park, which locates in the east of the mainland coast of Queensland, is the world's largest coral reef system that composed of nearly 3,000 individual reefs and 900 islands stretching for 2,600 kilometers. The whole cover area is more than 344,400 square kilometers. The reef is located in the Coral Sea, off the coast of Queensland in northeast Australia. In addition, washed by the warm waters of the South-West Pacific Ocean the perfect environment is created for this world's largest system of coral reefs (Dobbs et al., 2008). The Great Barrier Reef is of such pristine condition that it was listed by the World Heritage Trust as a protected site and is therefore managed by the Great Barrier Reef Marine Authority to make sure it can keep its natural views to attract visitors to come. The Figure 2 is the overlooking view of the Great Barrier Reef Marine Park.

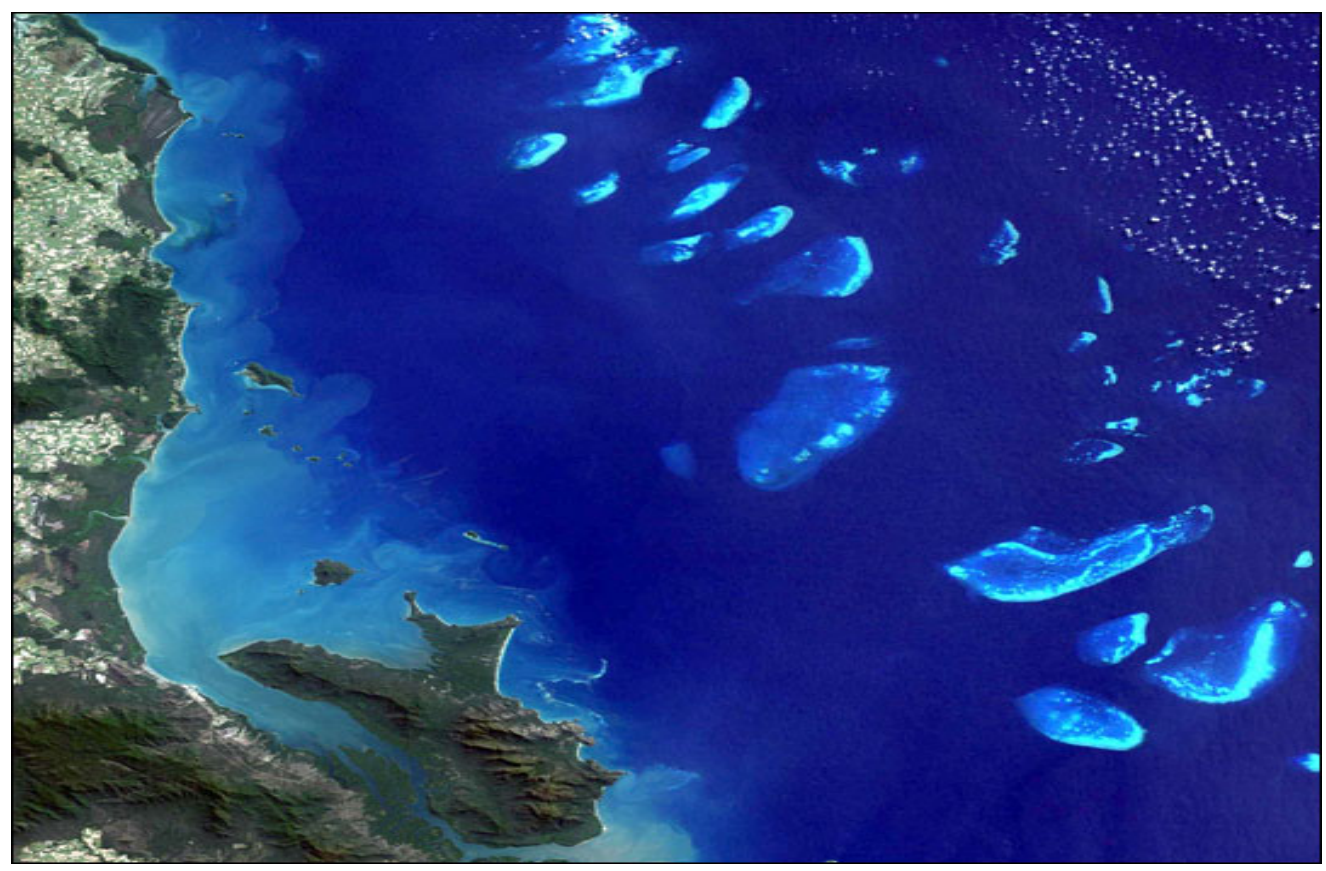

Figure 2. The overlooking view of the Great Barrier Reef Marine Park 
b). The Australian Whale Sanctuary was established in 1999 to protect dolphins and whales from hunting, depending on the Environment Protection and Biodiversity Conservation Act 1999 that all cetaceans, such as whales, dolphins and porpoises, are protected in Australian seas. The Australian Whale Sanctuary includes the Commonwealth marine area, beyond the coastal waters of each state and the Northern Territory, and even comprises all of Australia's Exclusive Economic Zone (EEZ) which is generally extends to nearly 370 kilometers from the coast (Jabour and Iliff, 2009). The Sanctuary is the scene of an ongoing controversy between Australia and Japan over whaling due to Japanese whaling industry. The Figure 3 is the area of the Australian Whale Sanctuary.

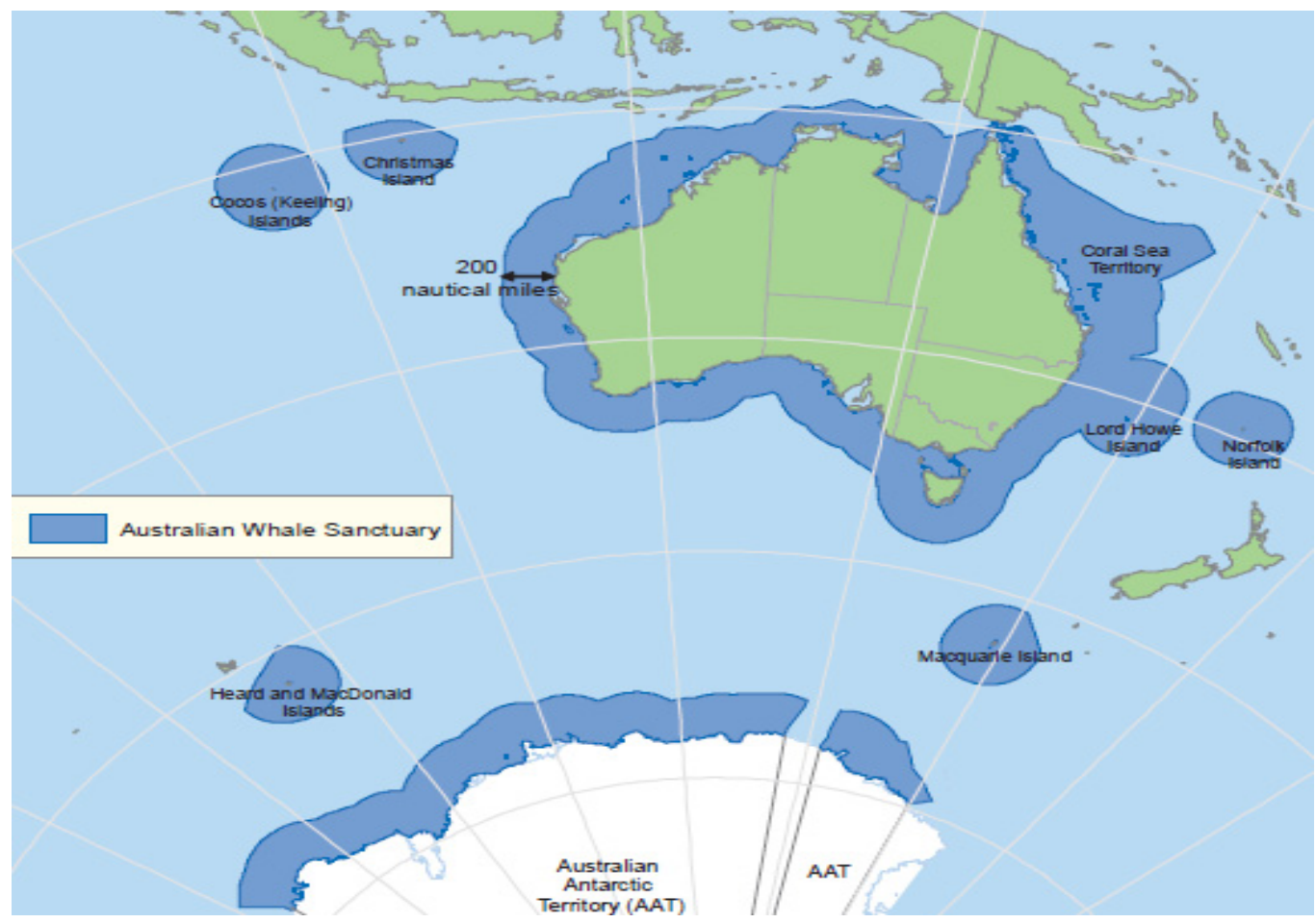

Figure 3. The area of the Australian Whale Sanctuary

c). The Huon Commonwealth Marine Reserve was established in 1999. The whole area of it covers about 9,991 square kilometers of Commonwealth ocean territory to the south of Tasmania, ranging from the inner continental shelf 70 meters to the abyss in more than 3,000 meters. This means that the major part of this marine reserve is in the deeper sea. Huon Commonwealth Marine Reserve contains a remarkable cluster of cone-shaped submerged mountains (seamounts), which are habitat for a diverse number plants and animals. In addition, there is a huge number of endemic species and large erect corals and sponges on the seabed. Moreover, there is hundreds of the flora and fauna at the bottom of the ocean and even some of them have the longest age on earth. Figure 4 is the map of the Huon Commonwealth Marine Reserve, and the area and location are clearly indicated on it. 


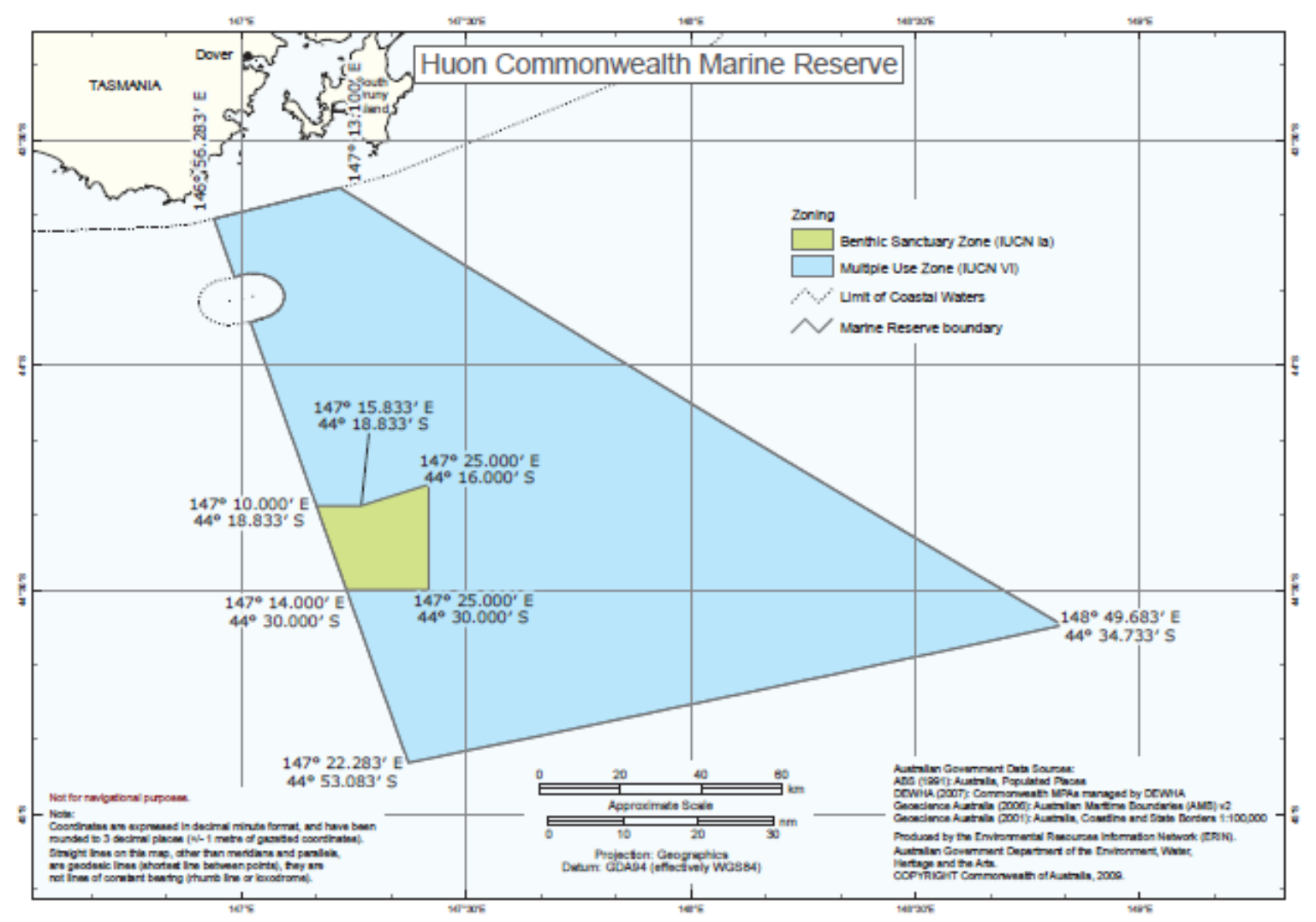

Figure 4. The map of the Huon Commonwealth Marine Reserve

\section{Designating Marine Reserves Is a Complex Process}

Marine reserves are the areas which will protect the marine species and keep ecosystem equal. Indeed, designating a marine reserve is a biological process. However, it is also related to the economic, environmental and social aspects, so designating marine reserves is a complex synthesis process.

\subsection{Designating Marine Reserves Is a Biological Process and a Environmental Protecting Process}

Preserve ecosystem properties or characteristics and the processes that control or regulate them are the one of common goals which is achieved marine reserves and marine reserve networks. This is true of both the ecosystems defined within the reserves and the larger ones of which they are a part. Within marine reserves, natural processes that preserve ecosystem structure have the opportunity to exercise their influence over the distribution and abundance of species, the interactions among species within an ecological community, and the pathways through which matter and energy flow (Kostylev et al., 2010). The Australian Whale Sanctuary is a good example for this. It has a recovery plan for five whale species such as blue whale, southern right whale, sei whale, fin whale and humpback whale, which are endangered. They consider the degradation of habitat and whaling are the key threat, and they will establish objectives and actions to ensure the ongoing recovery of the species.

In addition, marine ecology is recovered and the marine rare animals and plants are protected because of creating marine reserves, which is also a process of environmental protection such as the Great Barrier Reef Marine Park. Because the tourists picked a large number of coral reefs randomly in the past and lots of pollution water which was coming from agricultural lands with many harmful chemical residues was running into the marine, it destroyed the living environment of coral reefs. Moreover, the oil spill accidents always appeared in shallow waterway, which also resulted in marine pollution, and the coral reefs were disappearing at an alarming rate same as tropical rain forests (Kozlowski et al., 1988). As a consequence, the current reserve management authorities have taken strict measures to restrict the discharge of nearby agricultural using waters, enhance the safety of shallow water and actively support educational talks and publicities related to nature conservation for tourists in the entrance. These measures are protecting coral reefs in the Great Barrier Reef Marine Park. Therefore, designating marine reserves is a environmental protecting process. 


\subsection{Designating Marine Reserves Is an Economic Process}

With the human development, a huge number of ships are produced into ocean and a large area of it is exploited and used, which may result in marine natural resources depletion. In particular, the fisheries get a big affect because over-fishing makes the fish population in oceans with a sharp decline. Australia is a country which around with oceans and the fishery industry is a significant part of its economic structure. Keeping a steady and healthy marine fish resource is a vital point for Australia. It need to be noted that designating and creating marine reserves are good for avoiding ocean nature resource depletion and keep marine have sufficient fish populations (Hart and Sissenwine, 2009). As a consequence, the Australian government establishes a National Representative System of Marine reserves to protect the economic benefits for fishers.

Grafton, Tom and Pham (2006) propose two different Marine Reserves Bio-economic models: Deterministic Bioeconomic Models and Stochastic Models to determine whether the marine reserves are good for protecting fishers' economy. Finally they found that a marine reserve can generate economic payoffs not previously identified. The population is persistent and there exists no uncertainty over the size of the current population even if harvesting is optimal, but a marine reserve can increase resource rents and reduce the recovery time for a harvested population in the presence of negative shocks. The reason a reserve has economic value is because it allows for spillovers of fish from the reserve to the harvested population following a negative shock that can, in turn, raise resource rents (Grafton et al., 2006). The Great Barrier Reef Marine Park is another instance. It has become a new interest of place and local economic increasing point since it created. Every year, nearly millions of domestic and foreign tourists will visit this place. Therefore, designating marine reserves is an economic process.

\subsection{Designating Marine Reserves Has Many Social Implications}

Designating marine reserves is not only good for fishery and travel to get economic income but also it will often provide important ancillary benefits. For example, protecting coral reefs that store carbon and provide unique recreation opportunities, such as scuba diving or underwater photography, will yield benefits independent of fishery enhancement. In addition, individuals who may never visit the site but benefit from knowing that rare habitats exist and endangered species are protected might value, especially for some people who need to work in the marine. They will know these endangered species which they never know before need to be taken carefully (James, 2003).

Therefore, designating marine reserve will lead to social change. Marine reserves are not only the product of social processes, but they also have social ramifications. Marine reserves, like other forms of resource management, allocate access to and use of marine resources among individuals and social groups and, thereby directly and indirectly shape society. In Belize, for example, establishment of the Hol Chan Marine Reserve had far-reaching social impacts in the adjacent town of San Pedro. Reserve establishment catalyzed the transition of San Pedro from a fishing community to a tourism-based economy. Local men left the fishing industry for the higher wages they could garner working as tour guides for snorkelers and scuba divers in the new marine reserve (Jack, 2004). In addition, the relationship between marine reserve design and performance is complex and dynamic; just as reserve design influences performance, reserve performance influences design. It is critical to understanding of reserve emergence and evolution and to the design of effective reserve policy.

\section{Conclusion}

Marine reserves can protect ecosystem structure and functions, improve fishery, expand knowledge and understanding of marine system and enhance nonconsumptive opportunities. Therefore, designating marine reserves is not just an ecological process because it also an environmental protecting process, economic development and social advancement process. A good plan of designating marine reserves can recovery the marine ecosystem and reduce the pollution, which is good for marine environment. In addition, the favorable management and program are much useful to avoid the marine natural resource depletion as well as protect the economic income, especially for fishers. Furthermore, marine reserves will help people increase knowledge in order to make them know the rare ocean animals and plants which need to be protected. Marine reserves are also bringing many extra benefits for the area where the marine reserve located such as diving or underwater photography. As a consequence, designating marine reserves is also a environmental, economic and social complex process.

\section{References}

BOOKS, LLC. (2010). Marine Reserves of Australia: Pope's Eye, Port Phillip Heads Marine National Park, Australian Whale Sanctuary, Huon Commonwealth Marine Reserve. General Books press pp 1-26. 
Dobbs, K., Fernandes, L., Slegers, S., Jago, B., Thompson, L., Hall, J., ... Coles, R. (2008). Incorporating dugong habitats into the marine protected area design for the Great Barrier Reef Marine Park, Queensland, Australia. Ocean \& Coastal Management, 51, 368-375. http://dx.doi.org/10.1016/j.ocecoaman.2007.08.001

Grafton, R. Q., Kompas, T., \& Ha, P. V. (2006). The economic payoffs from marine reserves: Resource rents in a stochastic environment. Economic Record, 469 .480. http://dx.doi.org/10.1111/j.1475-4932.2006.00360.x

Hart, D. R. \& Sissenwine, M. P. (2009). Marine reserve effects on fishery profits: a comment on. In White et al. (Eds.), Ecology Letters, 12, E9-E11.

Jabour, J., \& Iliff, M. (2009). Theatre sports in the Southern Ocean: engagement options for Australia in whale research protest action. Australian Journal of International Affairs, 63, 268-289. http://dx.doi.org/10.1080/10357710802389488

Jack, A. S., \& Craig, D. (2004). Our oceans in troubles. Marine reserves: a guide to science, design, and use. Washington: island press Pp 4-28.

James, N. S., Kathryn, A. C., \& Peter, M. E. (2003). Marine Protected Areas: Economic and Social Implications. Washington D.C. Resources for the Future. 43, 10-18.

John, D. (2008). Effects of marine reserve protection on spiny lobster. Challenges to Marine Ecosystems: Proceedings of the 41st European Marine Biology Symposium. Netherlands: Springer press Pp 63-68.

Kostylev, E. F., Tkachenko, F. P., \& Tretiak, I. P. (2010). Establishment of "Zernov's Phyllophora field" marine reserve: Protection and restoration of a unique ecosystem. Ocean \& Coastal Management, 53, $203-208$. http://dx.doi.org/10.1016/j.ocecoaman.2010.04.010

Kozlowski, J., Rosier, J., \& Hill, G. (1988). Ultimate-Environmental-Threshold (UET) Method in a Marine-Environment (Great Barrier-Reef Marine Park in Australia). Landscape and Urban Planning, 15, 327-336. http://dx.doi.org/10.1016/0169-2046(88)90056-4

Pinheiro, H. T., Ferreira, A. L., Molina, R. P., Protti, L. M. C., Zanardo, S. C., Joyeux, J. C., \& Doxsey, J. R. (2009). Profile of social actors as a tool the definition of marine protected areas: the case of the Ilha dos Franceses, southern coast of Espirito Santo, Brazil. Natureza \& Conservacao, 7, 181-194.

Preen, A. (1998). Marine protected areas and dugong conservation along Australia's Indian Ocean coast. Environmental Management, 22, 173-181. http://dx.doi.org/10.1007/s002679900094

\section{Copyrights}

Copyright for this article is retained by the author(s), with first publication rights granted to the journal.

This is an open-access article distributed under the terms and conditions of the Creative Commons Attribution license (http://creativecommons.org/licenses/by/4.0/). 